\title{
Ocimum gratissimum: A Review of its Chemical, Pharmacological and Ethnomedicinal Properties
}

\author{
K.S. Prabhu ${ }^{1}$, R. Lobo ${ }^{1}$, A.A. Shirwaikar ${ }^{2}$ and A. Shirwaikar ${ }^{1, *}$ \\ ${ }^{I}$ Department of Pharmacognosy, Manipal College of Pharmaceutical Science, Manipal, Karnataka, India and ${ }^{2}$ Gulf \\ College of Pharmacy, Gulf Medical University, Ajman, UAE
}

\begin{abstract}
Ocimum gratissimum is a well-known plant used in the Indian system of medicine. Folklore medicine claims its use in headache, fever, diarrhoea, pneumonia etc. Research carried out using different in vitro and in vivo techniques of biological evaluation supports most of the claims. This review presents the ethnobotanical, natural product chemistry, pharmacological, clinical and toxicological data of the plant.
\end{abstract}

Key Words: Ocimum gratissimum, antifungal, antibacterial, essential oil.

\section{INTRODUCTION}

This review emphasizes the traditional use and clinical potentials of Ocimum gratissimum. Through this review, authors hope to attract the attention of natural product researchers throughout the world to focus on the explored potential of $O$. gratissimum.

This review has been compiled using references from major database such as Chemical Abstracts, Medicinal and Aromatic Plants Abstracts, Pubmed, Duke's Phytochemical and Ethnobotany database, United States Patent and Trademark Office (USPTO) Patent Full Text and Image database.

The available information on $O$. gratissimum has been divided into six sections, that is, ethnopharmacology, morphology, phytochemistry, pharmacological, clinical and toxicological studies. The ethnopharmacological section has been further subdivided into two sections, viz. traditional uses and alternative and complementary medicinal uses. The reports in which $O$. gratissimum have been used as a domestic remedy by common men without prescription for the treatment of various ailments have been discussed under traditional uses. The subhead "Alternative and Complementary medicinal uses" highlights $O$. gratissimum as medicine prescribed by medical practitioners for the treatment of various ailments.

O. gratissimum is a herbaceous plant which belongs to the Labiatae family. The plant is indigenous to tropical areas especially India and it is also in West Africa. In Nigeria, it is found in the Savannah and coastal areas. It is cultivated in Ceylon, South Sea Islands, and also within Nepal, Bengal, Chittagong and Deccan [1]. It is known by various names in different parts of the world. In India it is known by its several vernacular names, the most commonly used ones being Vriddhutulsi (Sanskrit), Ram tulsi (Hindi), Nimma tulasi (Kannada). In the southern part of Nigeria, the plant is called

*Address correspondence to this author at the Department of Pharmacognosy, Manipal College of Pharmaceutical Science, Manipal-576104, Karnataka, India; E-mail: annieshirwaikar@yahoo.com "effinrin-nla" by the Yoruba speaking tribe. It is called "Ahuji" by the Igbos, while in the Northern part of Nigeria, the Hausas call it "Daidoya" [2].

\section{ETHNOPHARMACOLOGY}

\subsection{Traditional Uses}

O. gratissimum has been used extensively in the traditional system of medicine in many countries. In the North east of Brazil, it is used for medicinal, condiment and culinary purpose. The flowers and the leaves of this plant are rich in essential oils so it is used in preparation of teas and infusion [3]. In the coastal areas of Nigeria, the plant is used in the treatment of epilepsy, high fever and diarrhoea [2]. In the Savannah areas decoctions of the leaves are used to treat mental illness [4]. O. gratissimum is used by the Ibos of Southeastern Nigeria in the management of the baby's cord, to keep the wound surfaces sterile. It is also used in the treatment of fungal infections, fever, cold and catarrh [5]. Brazilian tropical forest inhabitants use a decoction of $O$. gratissimum roots as a sedative for children [6]. People of Kenyan and sub Saharan African communities' use this plant for various purposes like viz., the leaves are rubbed between the palms and sniffed as a treatment for blocked nostrils, they are also used for abdominal pains, sore eyes, ear infections, coughs, barrenness, fever, convulsions, and tooth gargle, regulation of menstruation and as a cure for prolapse of the rectum [7]. In India, the whole plant has been used for the treatment of sunstroke, headache, influenza, as a diaphoretic, antipyretic and for its anti-inflammatory activity [8$10]$.

The tribals of Nigeria use the leaf extract in treatment of diarrhoea, while the cold leaf infusions are used for the relief of stomach upset and haemorrhoids [11]. The plant is commonly used in folk medicine to treat different diseases such as upper respiratory tract infections, diarrhoea, headache, diseases of the eye, skin diseases, pneumonia, cough, fever and conjunctivitis [12]. 
The infusion of $O$. gratissimum leaves is used as pulmonary antisepticum, antitussivum and antispasmodicum [13].

\subsection{Alternative and Complementary Medicinal Uses}

Among the various species of Ocimum, O. gratissimum finds extensive use clinically throughout the world. Formulations of the leaf essential oil of $O$. gratissimum (Ocimum oil) have been incorporated in a variety of bases as topical antiseptics and for use in the treatment of minor wounds, boils and pimples [14].

Ijeh I.I. (2005) reports that O. gratissimum and Xylopia aethiopica in combination are used in the preparation of potions and teas for women during peuperium [5].

\section{MORPHOLOGY AND MICROSCOPY}

\subsection{Morphology}

O. gratissimum is a shrub up to $1.9 \mathrm{~m}$ in height with stems that are branched. The leaves measure up to $10 \times 5 \mathrm{~cm}$, and are ovate to ovate-lanceolate, sub-acuminate to acuminate at apex, cuneate and decurrent at base with a coarsely crenate, serrate margin, pubscent and dotted on both the sides. The leaves show the presence of covering and glandular trichomes. Stomata are rare or absent on the upper surface while they are present on the lower surface. Ordinary trichomes are few, while the long ones up to 6-celled are present on the margins mostly; the short ones which are 2 celled, are mostly found on the lamina. Petioles are up to $6 \mathrm{~cm}$ long and racemes up to $18 \mathrm{~cm}$ long. The peduncles are densely pubescent. Calyx is upto $5 \mathrm{~mm}$ long, campanulate and 5-7 mm long, greenishwhite to greenish-yellow in colour. Nutlets are mucilaginous when they are wet [15] (Fig. (1)).

\subsection{Microscopy}

On the 2 surfaces of the leaf epidermal cells are typical of irregular contours, and diacytic stomata, secretory glands most abundant in the leaf, are also present in simple pluricellular hairs on the leaf veins. The cross section shows the epidermis monoestratificada (beam), a layer of parenchyma fenced in sub-epidermal position, followed by parenchymal pond, and finally the epidermis monoestratificada lower [16].

\subsection{Powder Microscopy}

Powder study was carried out by Lic Dinah Garcinia (1998) [18]. On examination following characters were observed (Fig. (2)).

\section{PHYTOCHEMISTRY}

Maria goretti de Vasconcelos Silva et al. worked on compositions of essential oil from Ocimum species obtained by steam, microwave and supercritical $\mathrm{CO}_{2}$ extraction. The report reveals the following components by GC-MS analysis (Table 2) [23].

Thin layer chromatography of the fractions isolated from O. gratissimum leaves indicated the presence of fairly polar compounds. Analysis of one of the components by mass spectra showed the presence of an unknown compound with a molecular mass of at least 353 daltons containing carbon, hydrogen, oxygen and possibly nitrogen. A tentative molecu- lar formula, as deduced from computer analysis, is either $\mathrm{C}_{21} \mathrm{H}_{37} \mathrm{O}_{4}$ or $\mathrm{C}_{19} \mathrm{H}_{35} \mathrm{~N}_{3} \mathrm{O}_{3}$ [25].

a)

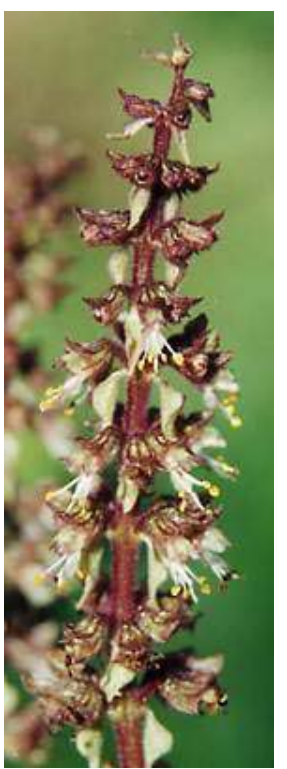

b)

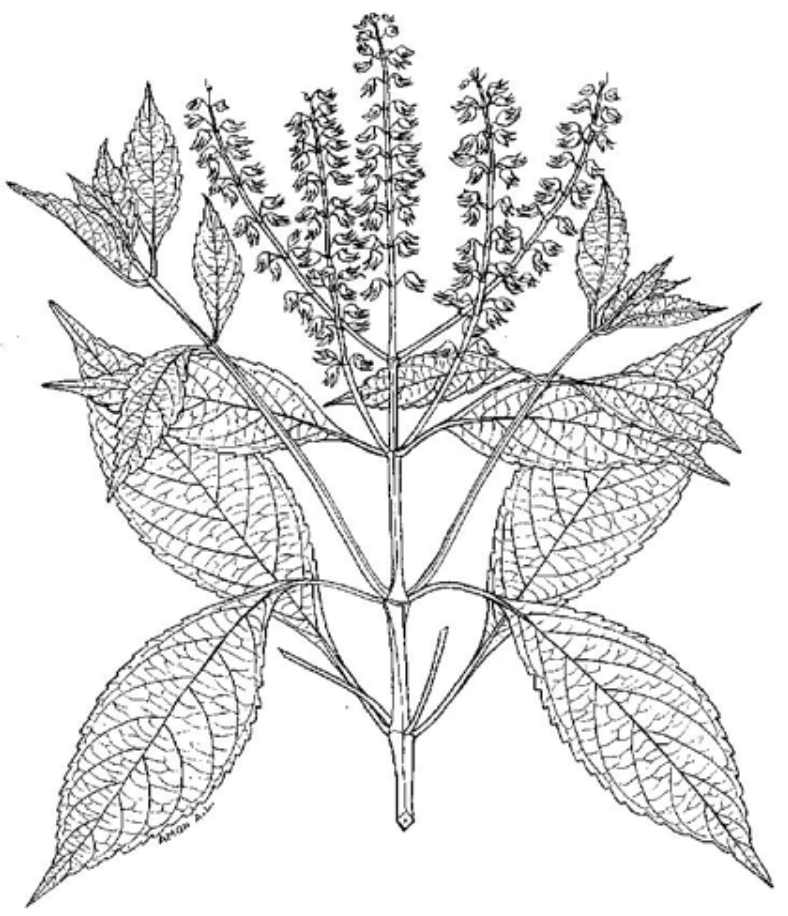

Fig. (1). a) Flowering tops of $O$. gratissimum. b) Whole plant $O$. gratissimum.

Cristiana M. Murbach Freire et al. carried out the experiment to determine the percentage composition of the essential oil obtained from fresh leaves of $O$. gratissimum in different seasons throughout the year. Percentage of the chemical constituents obtained in different seasons throughout the year has been shown in the (Table 3) [6]. 


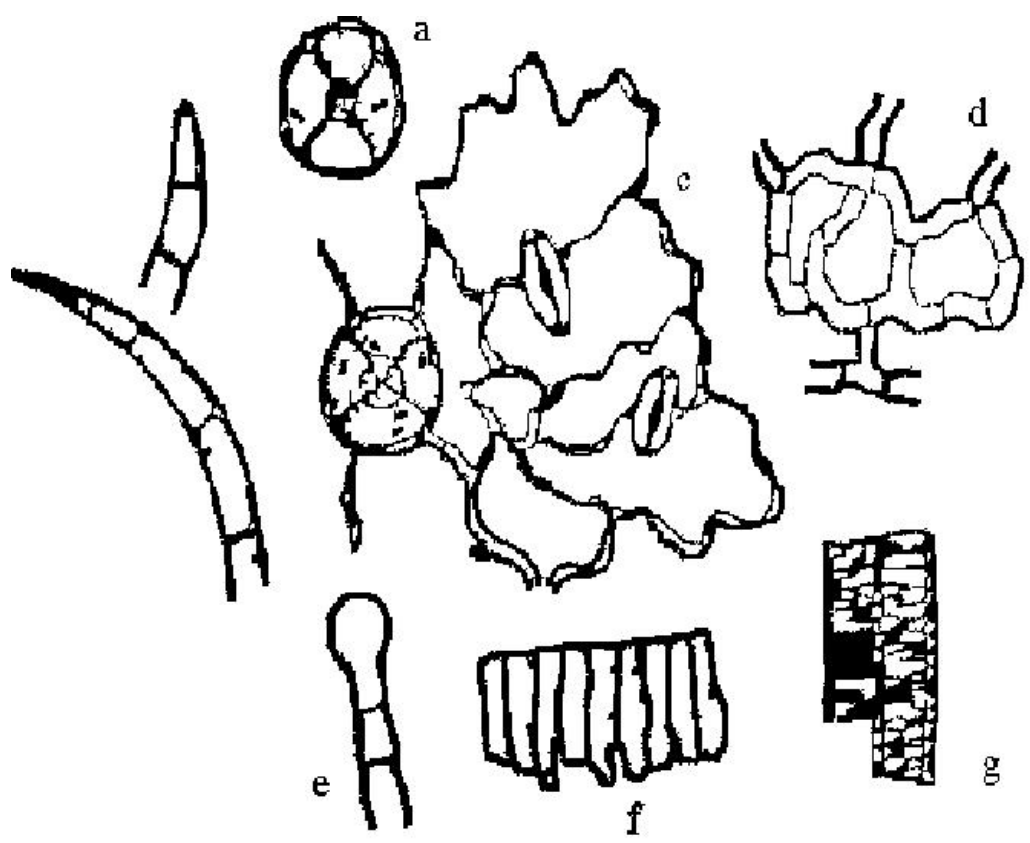

Fig. (2). Powder microscopy of $\boldsymbol{O}$. gratissimum. a) Pelos and non-glandular uniseriate pluricellular. b) gland view from the top of the head with 4 cells radiant. c) fragment of skin with glands and stomata. d) of leaf tissue lagoon. e) hair with glandular stalk multicellular. f) parenchyma fence. g) tracheal reticular.

Table 1. List of Biologically Active Compounds that have been Isolated from $O$. gratissimum

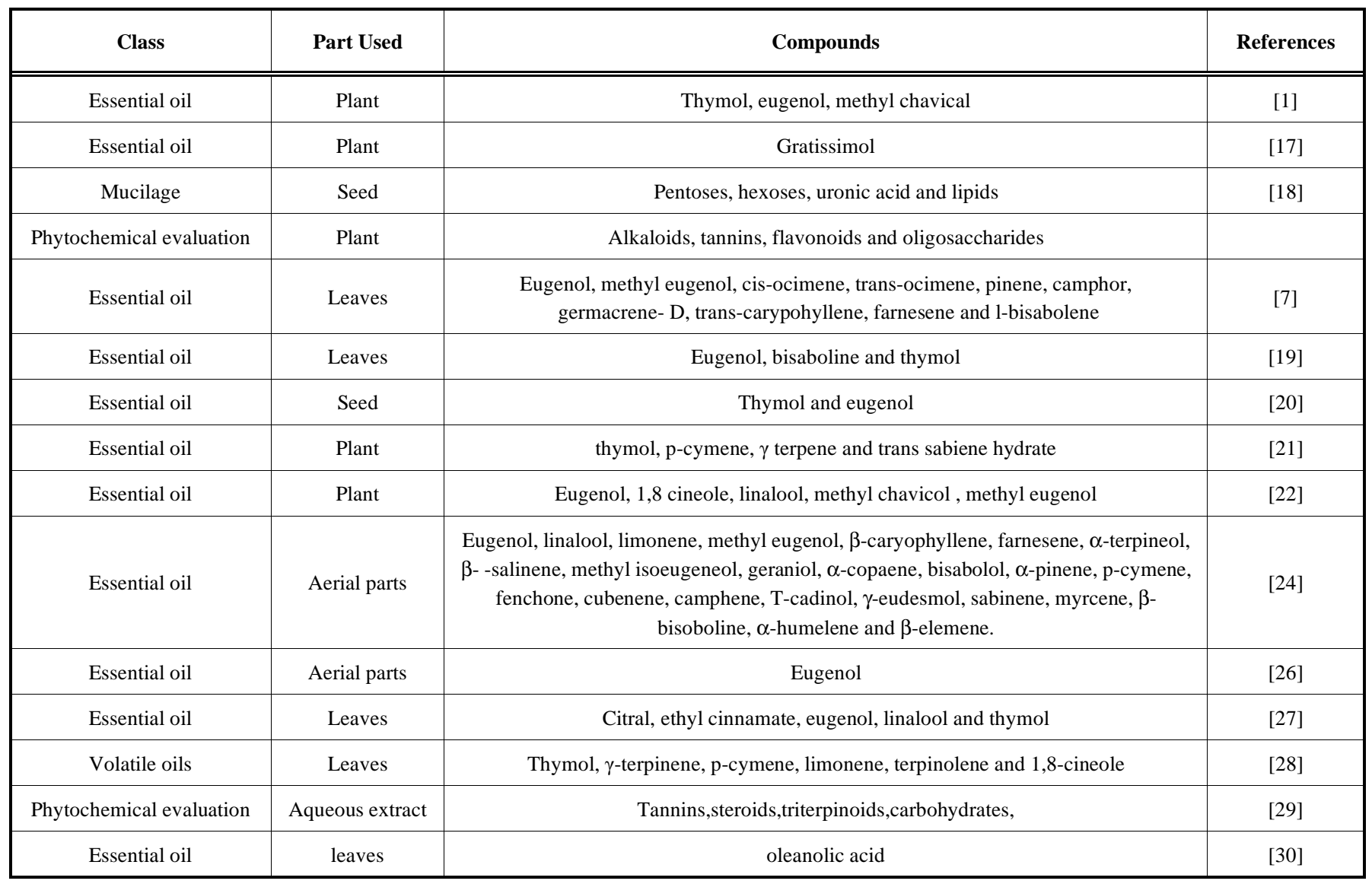


Table 2. Percentage Chemical Constituents Obtained by Different Methods from $O$. gratissimum Leaf

\begin{tabular}{|c|c|c|c|}
\hline Constituents & Steam Distillation \% & Hydrodistillation Using Microwave Oven \% & Supercritical CO O $_{2}$ \\
\hline \hline$\alpha$-pinene & 0.7 & - & - \\
\hline$\beta$-pinene & 2.6 & 22.6 & 5.6 \\
\hline 1,8 -cineole & 21.6 & 1.7 & - \\
\hline Ocimene & 4.1 & 1.6 & - \\
\hline$\alpha$-terpineol & 0.7 & 34.6 & 73.1 \\
\hline Eugenol & 54.0 & 10.5 & 5.6 \\
\hline$\beta$-caryophyllene & 5.3 & 1.6 & 0.8 \\
\hline$\alpha$-humulene & 0.8 & 4.7 & 1.6 \\
\hline$\gamma$-muurolene & 2.3 & 15.3 & 7.7 \\
\hline$\beta$-selinene & 5.5 & 6.1 & 2.4 \\
\hline$\alpha$-selinene & 2.6 & & \\
\hline
\end{tabular}

Table 3. Percentage Composition of the Essential oil Obtained from the Fresh Leaves of $O$. gratissimum in Different Seasons Throughout the Year

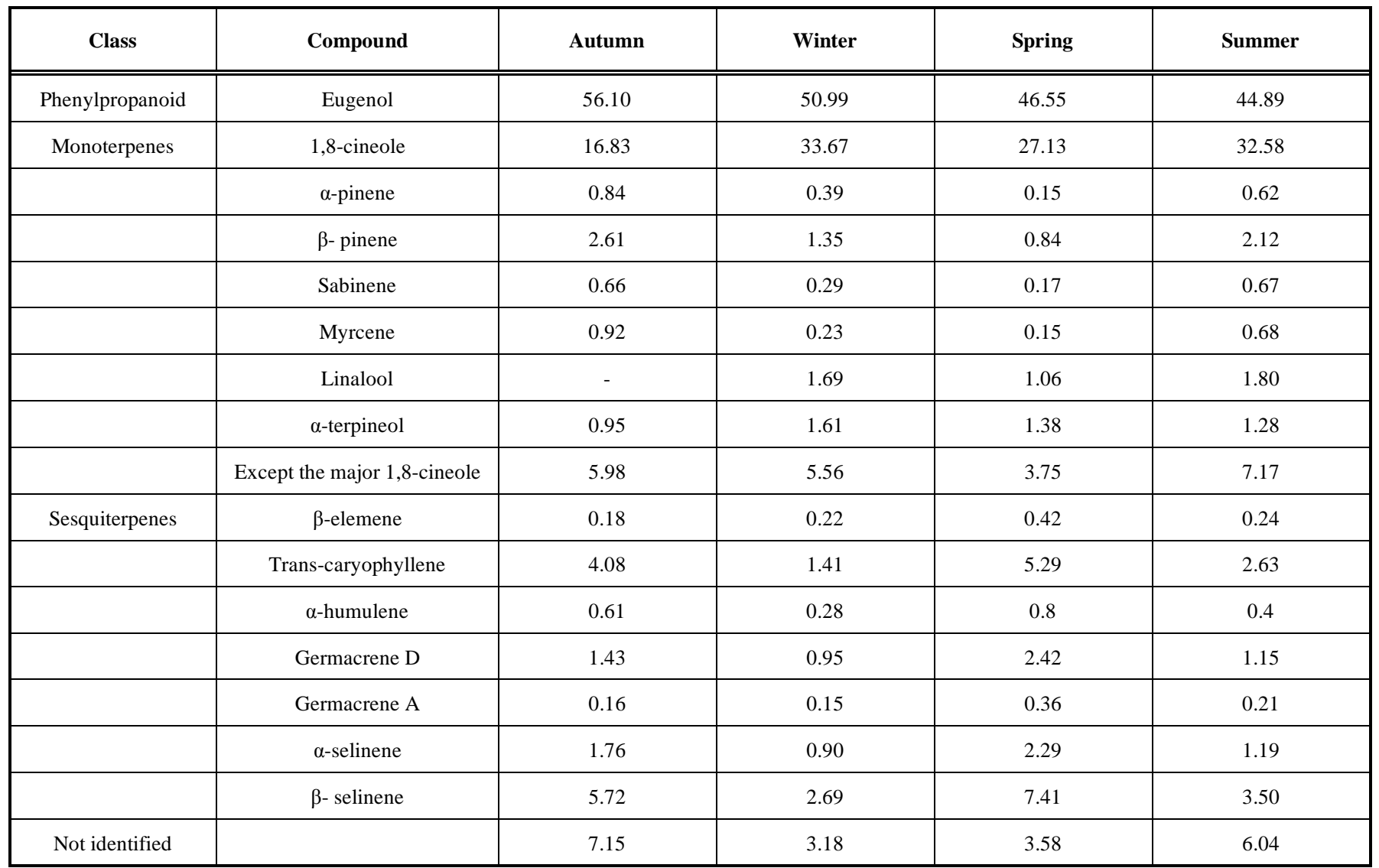

Variation of chemical composition of the essential oil of O. gratissimum eugenol type was studied for $11 \mathrm{~h}$ during the daytime. Microwave oven technique was used for the serial extraction and the obtained oils were analysed by GC/MS. A considerable variation was observed in the eugenol yield,
$98 \%$ at 12.00 a.m. to $11 \%$ at 05.00 p.m. These results show the influence of the solar light on eugenol production and can be useful to indicate the optimal time for collection of the plant (Table 4) [31]. 
Table 4. Daytime Hourly Variation of the Chemical Composition of $O$. gratissimum Leaf Essential Oil

\begin{tabular}{|c|c|c|c|c|c|c|c|c|c|c|c|}
\hline Constituents & 08.0 & 09.00 & 10.00 & 11.00 & 12.00 & 13.00 & 14.00 & 15.00 & 16.00 & 17.00 & 18.00 \\
\hline$\beta$-pinene & 3.7 & - & - & - & - & - & - & 2.0 & - & 2.7 & 1.3 \\
\hline Mircene & 1.6 & - & 1.0 & - & - & - & - & - & - & 0.8 & - \\
\hline Linalool & 1.5 & - & 7.9 & - & - & 1.4 & - & - & - & - & - \\
\hline 4-terpineol & 0.6 & - & 2.3 & - & - & 2.5 & - & - & - & - & - \\
\hline$\alpha$-terpineol & 1.1 & - & 1.8 & - & - & 1.8 & - & - & - & - & - \\
\hline Eugenol & 14.0 & 32.4 & 29.0 & 90.6 & 98.0 & 91.9 & 80.3 & 27.5 & 67.0 & 11.4 & 39.5 \\
\hline$\beta$-malilene & 4.8 & - & 12.2 & - & - & - & 11.5 & 2.4 & - & - & 13.4 \\
\hline
\end{tabular}

Table 1 and Fig. (3) gives the list of few biologically active compounds and their structures that have been isolated from $O$. gratissimum respectively.

\section{PHARMACOLOGICAL STUDIES}

\subsection{Antimicrobial and Antifungal Activity}

Honey is reported to have wound healing properties. Study was carried out to investigate the effect of honey as well as those of surfactants on the antibacterial activity of the essential oil of $O$. gratissimum. The antibacterial activity of dispersions of ocimum oil (2\%) in methanol, honey, a macrogol blend, nonionic and ionic emulsifiers were assessed by cup-plate method using type bacteria and wound isolates. Honey enhanced the antibacterial activity of ocimum oil to a greater extent than the macrogol blend. The activity of ocimum oil emulsion in cetrimide (cationic) was lower than obtained for cetrimide solution. Emulsion of the oil in sodium lauryl sulphate (anionic) exhibited a slightly higher activity than the solution of the surfactant alone. Although Tween ${ }^{\circledR} 20$ (nonionic) and aqueous methanol had no activity, the emulsion of the oil in Tween ${ }^{\circledR} 20$ showed lesser activity than the oil solution in methanol. Honey's inherent antibacterial activity, surfactant charge interaction and the effect of emulsification were adduced to the observed differences in antibacterial activity of the ocimum oil formulations. Findings indicated that honey was a suitable base for ocimum oil especially in the treatment of infected wounds [32].

An investigation of antifungal activity of the essential oil obtained by steam-distillation $(1.1 \% \mathrm{w} / \mathrm{w})$ of the aerial parts of $O$. gratissimum and of an ethanolic extract from the steam-distillation residue was carried out using the agar diffusion method. The results revealed that the essential oil inhibited the growth of all fungi tested, including the phytopathogens, Botryosphaeria rhodina, Rhizoctonia sp. and two strains of Alternaria sp., while the extract from the residue was inactive. The antifungal activity of eugenol was evaluated against a species of Alternaria isolated from tomato and
Penicillium chrysogenum. The minimal inhibitory concentrations of eugenol were 0.16 and $0.31 \mathrm{mg} /$ disc for Alternaria sp. and P.chrysogenum, respectively [26].

Cryptococcal infection had an increased incidence in last few year's due to the explosion of acquired immunedeficiency syndrome. $O$. gratissimum has been reported earlier with in vitro activity against some bacteria and dermatophytes. In vitro activity of the ethanolic crude extract, ethyl acetate, hexane, chloroform fractions, essential oil, and eugenol of $O$.gratissimum was studied using an agar rdilution susceptibility method towards 25 isolates of Cryptococcus neoformans. All the extracts of $O$. gratissimum studied showed activity in vitro towards $C$. neoformans. Based on the minimal inhibitory concentration values the most significant results were obtained with chloroform fraction and eugenol. It was observed that the chloroform fraction inhibited 23 isolates $(92 \%)$ of $C$. neoformans at a concentration of $62.5 \mu \mathrm{g} / \mathrm{ml}$ and eugenol inhibited 4 isolates (16\%) at a concentration of $0.9 \mu \mathrm{g} / \mathrm{ml}$ [19].

The antibacterial activity of different extracts from the leaves of $O$. gratissimum was tested against Staphylococcus aureus, Escherichia coli, Salmonella typhi and Salmonella typhimurium, pathogenic bacteria that cause diarrhoea. Extracts evaluated included cold water extract, hot water extract and steam distillation extract. Only the steam distillation extract had inhibitory effects on the selected bacteria and the minimum inhibitory concentration ranged from $0.1 \%$ for $S$. aureus to $0.01 \%$ for $E$. coli and $S$. typhimurium, and $0.001 \%$ for S. typhi [12].

Largely widespread in tropical countries, O. gratissimum has been claimed to possess for many uses in folk medicine. Antifungal activities were carried out by the agar dilution method using five chemotypes. Out of these five chemotypes, ethyl cinnamate showed better activity and was active against dermatophytes and Scopulariopsis breicaulis, causing skin mycosis and onychomycosis; against Cryptococcus neoformans, implicated in HIV disease and against Mala- 
<smiles>CC1=CCC2C(C)C1C(C(C)C)CCC2(C)C</smiles>

Alpha copaene<smiles>CC1=CCC(C)=CCC(C)(C)C=CC1</smiles>

Alpha humelene<smiles>C=C1CCC[C@]2(C)CC[C@@H](C(=C)C)C[C@H]12</smiles>

Beta selinene<smiles>CC(C)=CCC[C@@H](O)[C@H]1CC=C(C)CC1</smiles>

Bisabolo<smiles>C=CC(C)=CCC=C(C)CCC=C(C)C</smiles>

Farnesene<smiles>CC1=C2CC(C(C)(C)O)CC[C@]2(C)CCC1</smiles>

Gamma eudesmol<smiles></smiles>

Germacrene D<smiles>C=CC(C)=CCC=C(C)C</smiles>

Ocimene

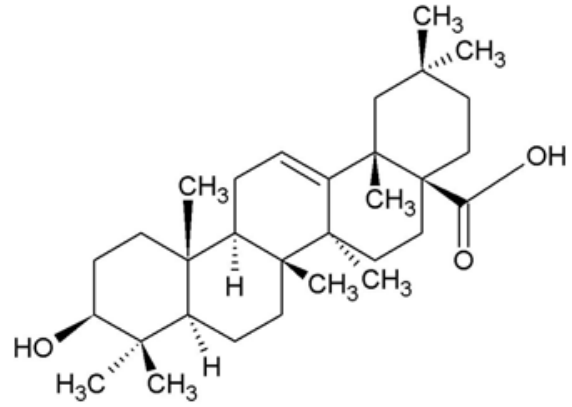

Oleanolic acid

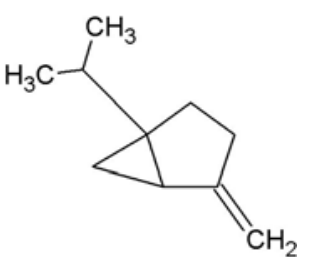

Sabinene<smiles>CC1=CCC(=C(C)C)CC1</smiles>

Terpinolene

Fig. (3). List of structures of few biologically active compounds that have been isolated from O. gratissimum.

ssezia pachydermatis, found in the dog's otitis externa. Due to these polyvalent performances and the sweet fragrance of this natural product, $O$. gratissimum essential oil containing a high level of ethyl cinnamate seems especially suitable for dermatology and cosmetology [27].

An exhaustive study was performed on stem bark parts by Kabir O Akinyemi et al., (2005) [33]. They attributed antimicrobial activity to the aqueous and ethanolic extract of $O$. gratissimum. Both the extracts were active against $S$. aureus and MRSA. They act as bacteriostatic at lower concentration and bactericidal at higher concentration. Minimum inhibitory concentration and minimal bactericidal concenteration were found to be between 18.2 to $24.0 \mu \mathrm{g} / \mathrm{ml}$ and 30.4 to $37.0 \mu \mathrm{g} / \mathrm{ml}$ respectively. Their results offer a scientific basis for the traditional use of water and ethanol extracts of $O$. gratissimum against MRSA-associated diseases [34].

The essential oil of $O$. gratissimum inhibited $S$. aureus at a concentration of $0.75 \mathrm{mg} / \mathrm{ml}$. The essential oil was also active against members of the family Enterobacteriaceae. The minimal inhibitory concentrations (MICs) for Shigella flexineri, Salmonella enterittis, Escherichia coli, Klebsiella sp., and Proteus mirabilis were at concentrations ranging from 3 to $12 \mu \mathrm{g} / \mathrm{ml}$. The minimum bactericidal concentration of the essential oil was within a twofold dilution of the MIC for this organism. The compound that showed antibacterial activity in the essential oil of $O$. gratissimum was identified as eugenol [33].

Lima et al. (1993) tested in vitro antifungal activity of thirteen essential oil obtained from plants against dermatophytes. Of the tested oils, $O$. gratissimum was found to be the most active, inhibiting $80 \%$ of the dermatophyte strains tested and producing zones greater than $10 \mathrm{~mm}$ in diameter [35].

Hydro-distilled volatile oils from the leaves of $O$. gratissimum from Meru district in Eastern Kenya were evaluated for antimicrobial activity. The antimicrobial activities of the essential oils were evaluated against both Gram positive ( $S$. aureus, Bacillus spp.) and Gram negative (E. coli, P. aeruginosae, S. typhi, $K$. pneumoniae, $P$. mirabilis) bacteria and a pathogenic fungus Candida albicans. The minimum inhibitory concenteration of oil for gram negative bacteria ranged from 107 to $750 \mathrm{mg} / \mathrm{ml}$ and 93.7 to $150 \mathrm{mg} / \mathrm{ml}$ for gram positive bacteria. The minimum inhibitory concenteration for the fungus $C$. albicans was $50 \mathrm{mg} / \mathrm{ml}$. The minimum inhibitory concenteration values for chloramphenicol ranged from 22.5 to $31.3 \mathrm{mg} / \mathrm{ml}$. The oil had pronounced antibacterial and antifungal activities on all the microbes [7]. 
The antibacterial effect of $O$. gratissimum extracted from the aromatic plant was investigated against Listeria monocytogenes serotype 4a. Agar well diffusion and tube dilution methods were used and the data recorded demonstrated antibacterial activity of the essential oil against the test bacteria. The bacterium was grown at $37^{\circ} \mathrm{C}$ in a chemically defined or a complex medium, containing essential oil obtained from $O$. gratissimum. At concentrations from 20 to $250 \mu \mathrm{g} / \mathrm{ml}$, the essential oil progressively inhibited the bacterial growth. The bacteria cultivated on chemically defined medium were more sensitive to essential oil at concentrations of 50,62.5 and $100 \mu \mathrm{g} / \mathrm{ml}$ in relation to those cultivated in complex medium at $37^{\circ} \mathrm{C}$. The agar well diffusion was also evaluated. The results yielded a zone of inhibition of $25 \mathrm{~mm}$. These established a good support to the use of this plant in herbal medicine and a base for the development of new drugs and phytomedicine [36].

The antibacterial activity of different extracts from the leaves of $O$. gratissimum was tested against S. aureus, E. coli, S. typhi and S. typhimurium, pathogenic bacteria that cause diarrhoea. The extracts evaluated included cold water extract, hot water extract and steam distillation extract. Only the steam distillation extract had inhibitory effects on the selected bacteria. The MIC ranged from $0.1 \%$ for $S$. aureus to $0.01 \%$ for $E$. coli and $S$. typhimurium, and $0.001 \%$ for $S$. typhi [12].

Effects of leaf extracts of $O$. gratissimum on spore germination and mycelial reduction of the most commonly occurring fungal pathogen causing soft rot of yam tuber were investigated. Fungi isolated from rotted yams were Aspergillus niger, A. flavus, Fusarium oxsporium Rhizopus stolonifer, Botryodiplodia theobromae and Penicillium chrysogenum. The ethanol leaf extract was most effective followed by cold-water and hot water extracts [37].

Essential oils extracted by hydrodistillation from local plants in Benin, western Africa were evaluated in vitro and in vivo for their efficacy against Fusarium verticillioides infection and fumonisin contamination. O. gratissimum was found to be the most effective in vitro, completely inhibiting the growth of $F$. verticillioides at lower concentrations over 21 days of incubation. These oils reduced the incidence of $F$. verticillioides in corn and totally inhibited fungal growth at concentrations of $8,6.4$, and $4.8 \mu \mathrm{l} / \mathrm{g}$, respectively, over 21 days. At the concentration of $4.8 \mu \mathrm{l} / \mathrm{g}$, these oils did not affect significantly fumonisin production. However, a marked reduction of fumonisin level was observed in corn stored in closed conditions. The oils adversely affected kernel germination at $4.8 \mu \mathrm{l} / \mathrm{g}$ and therefore cannot be recommended for controlling $F$. verticillioides on stored corn used as seeds, when used at this concentration [38].

Hexane extract of $O$. gratissimum leaves and eugenol were investigated for in vitro antifungal activity, using agar dilution technique against dermatophytes. The extracts (hexane, chloroform fractions, the essential oil and eugenol) produced antifungal activities against Microsporum canis, M. gypseum, Trichophyton rubrum and T. mentagrophytes. The hexane fraction and eugenol were the most active. Hexane fraction inhibited the growth of $100 \%$ of dermatophytes at a concentration of $125 \mu \mathrm{g} / \mathrm{ml}$, while eugenol inhibited the growth of $80 \%$ of dermatophytes at this same concentration. These results show that extracts of $O$. gratissimum are active in vitro against human pathogenic dermatophytes [39].

A study was carried out to determine the repellent activity of $O$. gratissimum volatile oil against Simulium damnosum (blackflies). A 12 month field study was conducted in three onchocerciasis endemic communities (Idomido, Obio camp, and Ikot Adaha) in Ini Local Government Area of Akwa Ibom State, Nigeria. The results revealed that topical application of $20 \% \mathrm{v} / \mathrm{v}$ concentration of the oil with liquid paraffin as a base reduced the biting rate of $S$. damnosum by 90.2 , 81.6, and 79.7\%, in Idomido, Obiocamp, and Ikot Adaha respectively. The oil gave protection against the bite of $S$. damnosum for at least $3 \mathrm{~h}$. A total of 710 adult $S$. damnosum were caught by individuals treated with Ocimum oil, as against 4296 caught by the control group. When the flies caught by the treated individuals were dissected none of them were infected with microfilariae of Onchocerca volvulus [40].

O. gratissimum leaves from Cameroon are a potential source of essential oil. Bioactivities were tested on the insect pest Sitophilus zeamais, which is the major pest of stored maize. Insecticidal activity was tested by putting 20 adult representatives of $S$. zeamais with $20 \mathrm{~g}$ of maize grains powdered with various mixtures of essential oil and kaolin (5 and $10 \%$ ). The tested essential oils of $O$. gratissimum protected $74 \%$ of the test-material against the $S$. zeamais population after 4 days. A direct application of the $O$. gratissimum on the test insects, was found to be $85.7 \%$ by knock down effect [28].

The effect of the essential oil of $O$. gratissimum on Herpetomonas samuelpessoai, a nonpathogenic trypanosomatid was observed. Parasites were grown at 28 or $37^{\circ} \mathrm{C}$, in a chemically defined or a complex medium, containing essential oil obtained from $O$. gratissimum. At concentrations from 20 to $250 \mu \mathrm{g} / \mathrm{ml}$, the essential oil, progressively inhibited the protozoan growth. The inhibitory concenteratuion $\left(\mathrm{IC}_{50}\right)$, in defined and complex media, at $28^{\circ} \mathrm{C}$ was 100 and $91 \mu \mathrm{g} / \mathrm{ml}$, respectively. Cells cultivated in a chemically defined medium were more sensitive to essential oil at concentrations of $50,62.5$ and $100 \mu \mathrm{g} / \mathrm{ml}$ in relation to those cultured in complex medium at $37^{\circ} \mathrm{C}$. In addition, ultrastructural and enzymatic alterations of the trypanosomatid were also evaluated. H. samuelpessoai exposed to $100 \mu \mathrm{g} / \mathrm{ml}$ of essential oil, in chemically defined medium at $28^{\circ} \mathrm{C}$ for $72 \mathrm{~h}$, presented considerable ultrastructural alteration, mainly at mitochondrial level, as showed by transmission electron microscopy. Furthermore, cells cultivated in the presence of 100 $\mu \mathrm{g} / \mathrm{ml}$ of essential oil showed a decrease of activity of the succinate cytochrome c reductase enzyme, a typical mitochondrion marker, as compared to untreated cells [41].

All the bacteria were susceptible on a different scale to the undiluted oils. The inhibition zone of the undiluted oil of O. gratissimum is more extensive than that of the other oil. The most susceptible strains are B. cereus and E. faecalis. The least sensible strains are B. subtilis, C. glutamicum and $E$. coli, while the other ones show a medium susceptibility. The subsceptibilities of the strains changed with the dilution of the essential oils with Tween 80 . Using a dilution of $1 / 30$ of essential oils all the strains have practically no susceptibil- 
ity any more, expect $B$. subtilis. The pure, undiluted essential oils of fresh leaves of $O$. gratissimum showed the most extensive inhibition zones and are, therefore, very effective antimicrobial systems. Table $\mathbf{2}$ shows the Inhibition zone (mm) using the essential leaf oil of $O$. gratissimum [13].

Alabi, D.A. et al. carried out the testing of four botanicals for fungitoxic property. It was observed that $O$. gratissimum exhibited mild activity compared to the other three [42].

Hot and cold water leaf extracts of $O$. gratissimum were effective in reducing the spore germination and radial growth of Colletotrichum lindemuthianum in vitro and the growth of the pathogen in vivo [43].

Mbata et al. showed that $O$. gratissimum oils have properties that can inhibit the growth of psychrophils and heat resistant organisms and suggested that the plant and its derivatives can be used for the primary purpose of flavouring foods and for antimicrobial activities [36].

\subsection{Ovicidal Activity}

The ovicidal activity of the essential oil of $O$. gratissimum and its main component eugenol was evaluated against Haemonchus contortus, a gastrointestinal parasite of small ruminants. The oil and eugenol were diluted in Tween $20(0.5 \%)$ at five different concentrations. In the egg hatch test, $H$. contortus eggs were obtained from the faeces of goats experimentally infected. At $0.50 \%$ concentration, the essential oil and eugenol showed a maximum eclodibility inhibition. These results suggest a possible utilization of the essential oil of O.gratissimum as an aid to the control of gastrointestinal helmintosis of small ruminants [44].

\subsection{Leishmanicidal Activity}

Study carried out by Luize PS et al. showed that hydroalcholic extract of $O$. gratissimum showed good leishmanicidal activity against Leishmania amazonensis compared to that of Trypanosoma cruzi. O. gratissimum showed inhibition of $91.5 \%$ at a concenteration of $100 \mu \mathrm{g} / \mathrm{ml}$. Along with leishmanicidal activity, haemolytic activity of the extract was also observed. At a concentration of $1000 \mu \mathrm{g} / \mathrm{ml}$ the extract showed $25 \%$ lysis of the cell, while no lysis was seen at a concentration of 500 and $100 \mu \mathrm{g} / \mathrm{ml}$. At the end of 120 min there was increase in lysis of cell to $75 \%$ and no lysis was seen at concentration of 500 and $100 \mu \mathrm{g} / \mathrm{ml}$ [45].

The essential oils obtained by hydrodistillation from fresh leaves of $O$. gratissimum growing in Cameroon were analyzed. The effects of these oils on the growth of Plasmodium berghei were investigated. Oils showed significant antimalarial activities in the four-day suppressive in vivo test in mice. At concentrations of 200,300 and $500 \mathrm{mg} / \mathrm{kg}$ of mouse per day, the essential oil of $O$. gratissimum at the same concentrations were $55.0 \%, 75.2 \%$ and $77.8 \%$, respectively. Chloroquine $(10 \mathrm{mg} / \mathrm{kg}$ of mouse, positive control) had a suppressive activity of $100 \%$. [46].

\subsection{Antidiarrhoeal Effect}

The aqueous extract of the leaves of $O$. gratissimum was screened for antidiarrhoeal effects. The extract inhibited castor oil-induced diarrhoea in rats as judged by a decrease in the number of wet faeces in the extract-treated rats. In addi- tion, the extract inhibited the propulsive movement of the intestinal contents. On the isolated ileum of guinea-pig, the extract showed no direct action; however, it reduced the responses of the guinea-pig ileum to acetylcholine, nicotine and histamine. The findings suggested that the aqueous extract of the leaves of O.gratissimum might elicit an antidiarrhoeal effect by inhibiting intestinal motility, partly via muscarinic receptor inhibition [29].

The antidiarrhoeal activities of leaf extracts of $O$. gratissimum were investigated by disc diffusion and tube dilution methods. The extracts were active against Aeromonas sobria, E. coli, Plesiomonas shigelloides, S. typhi, and Shigella dysenteriae. The leaf extracts were most active against $S$. dysenteriae and least active against $S$. typhi. The sensitivity of the organisms measured in terms of zone of inhibition ranged from 8.00 to $19.50 \mathrm{~mm}$. The minimum inhibitory concentrations were from 4 to $50 \mathrm{mg} / \mathrm{ml}$, while the minimum bactericidal concentration ranged from 8.00 to $62 \mathrm{mg} / \mathrm{ml}$ [47].

The anti-diarrhoeal property of the aqueous extract of $O$. gratissimum was investigated in Wistar albino rats. The aqueous leaf extract of this plant, at various doses tested (25, $50 \& 100 \mathrm{mg} / \mathrm{kg}$ body weight) displayed remarkable antidiarrhoeal activity evidenced by the reduction in the rate of defacation and consistency of faeces in albino rats. The protective role of $O$. gratissimum extract at $100 \mathrm{mg} / \mathrm{kg}$ body weight was comparable to that of the reference drug, diphenoxylate $(50 \mathrm{mg} / \mathrm{kg}$ body weight). O. gratissimum extract mimicked the action of adrenaline and noradrenaline on isolated guinea pig ileum by abolishing the acetylcholine induced contraction of the smooth muscles of ileum and also exhibited anti-inflammatory action against agar induced rat paw oedema in the dose range of 100 to $400 \mathrm{mg} / \mathrm{kg}$ body weight. Like phenylbutazone, the ability of the extract to block oedemogenesis was more manifest at the second phase after induction of inflammation of the reactions [48].

$O$. gratissimum leaf extracts have been extensively demonstrated to be effective against the various aetiologic agents of diarrhoea, including Shigellae. Study investigated the effects of $O$. gratissimum essential oil at sub-inhibitory concentrations of 0.75 and $1.0 \mu \mathrm{g} / \mathrm{ml}$ on virulent and multidrug-resistant strains of 22 Shigella isolates from Nigeria. Compared with untreated Shigella strains, O. gratissimum caused significant decreases $(\mathrm{p}<0.01)$ in extracellular protease activity, o-lipopolysaccharide rhamnose content and incidence of invasiveness mediated as keratoconjunctivitis in guinea pig. The disparity in extracellular protease activity and o-lipopolysacharide rhamnose between the two treatment groups was also found to be significant $(\mathrm{p}<0.05)$, suggesting greater anti-virulent effects of $O$. gratissimum oil at $1.0 \mu \mathrm{g} / \mathrm{ml}$. Antibiotic susceptibility testing revealed that the essential oil of $O$. gratissimum reduced the MICs of antibiotics to which Shigellae showed resistance by $9.8-53.1 \%$ and fluoroquinolones by $18.2-45.5 \%$. The results of this study strongly suggest inhibition of extracellular protease and expression of O-LPS rhamnose in Shigellae by O. gratissimum [20].

\subsection{Gastro Intestinal Tract}

The relaxant action of the essential oil of $O$. gratissimum is likely to be due to a direct effect on the smooth muscle of the ileum rather than an indirect action on neurotransmitter release, because a full reversal of the contraction induced by 
high $(60 \mathrm{mM}) \mathrm{KCl}$. Under these conditions, the plasmalemmal membrane of guinea pig enteric neurons is sufficiently depolarised to prevent the generation of action potentials. Additionally, essential oil of $O$. gratissimum was able to completely reverse $\mathrm{ACh}$-induced tonic contractions, in a slightly less potent manner than in $\mathrm{KCl}$-precontracted tissues, in agreement with a direct action of the essential oil on the smooth muscle. It is possible that the relaxant action of essential oil of $O$. gratissimum may be linked to a therapeutic sedative effect of the gastrointestinal tract. It is also possible that the combined effect of several chemical constituents of the plant is responsible for a final therapeutic effect. The principal chemical components identified in the present study were 1,8-cineole and eugenol. Further detailed studies on the components of essential oil of $O$. gratissimum are required to clarify the pharmacological action of this oil on the guinea pig ileum [49].

The effect of aqueous extract of the leaves of $O$. gratissimum on intestinal transit was determined in experimental rats. $10 \%$ extracts of powders were made and administered orally to rats at varying doses. Test rats were given the $10 \%$ extracts of $O$. gratissimum and control rats received saline instead of extracts. After $30 \mathrm{~min}$, each animal was then given $1.5 \mathrm{ml}$ of a dye solution orally. $1 \mathrm{~h}$ after administering the dye each rat was sacrificed and the intestine carefully dissected out. The length of the intestine and the transit point of the orally administered dye were then measured. The transit point was calculated as a percentage of the total length of the intestine. The extracts of $O$. gratissimum caused a reduction in the transit points of the dye. The reduction in transit point, and hence the increase in transit time by both extracts indicates that the plants could be useful at appropriate doses in the control of diarrhoea [50].

The medicinal plant $O$. gratissimum is widely encountered in the Northeast of Brazil where it is used to treat digestive problems. Leaves have an essential oil (EOOG) content whose chemical composition varies according to the time of plant collection. Madeira et al. have compared the effects of the EOOG, collected at 08:00 a.m. $\left(\mathrm{EOOG}_{8}\right)$ and at 12:00 a.m. $\left(\mathrm{EOOG}_{12}\right)$, on the relaxation of guinea-pig isolated ileum. Both $\mathrm{EOOG}_{8}$ and $\mathrm{EOOG}_{12}(30-300 \mu \mathrm{g} / \mathrm{ml})$ reversibly relaxed the spontaneous tonus of the guinea-pig ileum in a concentration-dependent manner, with similar $\mathrm{IC}_{50}$ values. The magnitude of the decrease in resting tonus was similar to that of the recognised smooth muscle relaxant papaverine. EOOG 8 and $\mathrm{EOOG}_{12}$ relaxed $60 \mathrm{mM} \mathrm{KCl-}$ precontracted preparations similarly $(38.33 \pm 9.91 \mu \mathrm{g} / \mathrm{ml}$ and $35.53 \pm 6.70)$, whereas a significantly more potent relaxant effect of $\mathrm{EOOG}_{12}$ compared to $\mathrm{EOOG}_{8}$ was observed when tissues were contracted using $10 \mu \mathrm{M}$ acetylcholine The principal constituents of the essential oil, eugenol and cineole, also relaxed $\mathrm{KCl}$-precontracted preparations, although they were less potent than EOOG. Results showed that the essential oil extracted from the leaves of $O$. gratissimum, collected at different time periods, exerts significant relaxant effects on isolated guinea-pig ileum which may underlie the therapeutic action of the plant [51].

\subsection{Wound Healing}

Persistent microvascular hyperpermeability to plasma proteins is a characteristic feature of normal wound healing.
Evan's blue dye (20mg/kg body weight) in normal saline was administered intravenously through marginal ear vein of experimental rabbits $(n=5)$. Each animal served as its own control. One hour after Evan's blue dye administration, $0.1 \mathrm{ml}$ each of $O$. gratissimum oil, histamine dihydrochloride $(30 \mu \mathrm{g} / \mathrm{ml})$ and normal saline were randomly administered by intra-dermal injection at the prepared sites on each of the animals. Increase in vascular permeability was assessed by dye effusion test. Analysis of the differences in vascular permeability between treatment groups showed that, $O$. gratissimum oil, in intensity and duration, was significantly $(\mathrm{p}<0.05)$ more effective in increasing cutaneous capillary permeability over a $24 \mathrm{~h}$ period after treatment. The ability of $O$. gratissimum oil in increasing vascular permeability may be one of the factors that contribute to its wound healing property [52].

\subsection{Anti-Inflammatory}

The following study report the inhibitory effect produced by chemical constituents of essential oils of three plants used in traditional medicine as anti-inflammatory and analgesic drugs, in vitro, on soybean lipoxygenase L-1 and cyclooxygenase function of prostaglandin $\mathrm{H}$ synthase (PGHS), the two enzymes involved in the production of mediators of inflammation. The essential oils were extracted from plants O.gratissimum along with two more plants. Among the three essential oils, O.gratissimum inhibited the two enzymes, cyclooxygenase function of PGHS and lipoxygenase L-1, with an $\mathrm{IC}_{50}=125 \mu \mathrm{g} / \mathrm{ml}$ and $144 \mu \mathrm{g} / \mathrm{ml}$ [53].

\subsection{Analgesic Activity}

The pharmacological activities of aqueous extracts of $O$. gratissimum was screened for isolated rabbit jejunum (IRJ); rat stomach strip (RSS); and analgesic properties in mice. The extract caused a dose-dependent inhibition of the rabbit jejunum spontaneous pendular movement. The blocking effect on acetylcholine induced contraction was non-competitive in the rat stomach strip since maximum contractions were suppressed and no parallel shift was observed in the curve. The result of the analgesic study showed that the extract evoked a prolongation of reaction time of $85 \%$ over 20 min observation time with no overt signs of toxicity. The results suggest the presence of analgesic and spasmolytic activities [54].

\subsection{Antimutagenic}

Obaseiki-Ebor et al. investigated the antimutagenic activity of $O$. gratissimum leaves extract along with other three edible vegetable plant. O. gratissimum showed inhibitory activity against $S$. typhimurium [55].

\section{CYTOTOXIC ACTIVITY}

Cytotoxic study was carried out on oleanic acid isolated from leaves of ethanolic extract of $O$. gratissimum. Effective dose of the compound at $50 \%$ concenteration $\left(\mathrm{ED}_{50}\right)$ to be tested against a panel of six human solid tumor cell lines viz. human lung carcinoma $\left(\mathrm{ED}_{50} 3.16 \mu \mathrm{g} / \mathrm{ml}\right)$, human breast carcinoma $\left(\mathrm{ED}_{50} 2.46 \mu \mathrm{g} / \mathrm{ml}\right)$, human colon adenocarcinoma. $\left(E_{50} 3.12 \mu \mathrm{g} / \mathrm{ml}\right)$ human renal carcinoma. $\left(\mathrm{ED}_{50} 3.13\right.$ $\mu \mathrm{g} / \mathrm{ml})$, human prostate adenocarcinoma $\left(\mathrm{ED}_{50} 2.58 \mu \mathrm{g} / \mathrm{ml}\right)$ 
human pancreatic carcinoma $\left(\mathrm{ED}_{50} 3.47 \mu \mathrm{g} / \mathrm{ml}\right)$, and yellow fever mosquito larvae Aedes aegypti. $\left(\mathrm{LC}_{50} 4.4 \mu \mathrm{g} / \mathrm{ml}\right)$ [30].

The essential oils isolated from the leaves of $O$. gratissimum were tested for their cytotoxic activity against P388 leukemia cells. The $\mathrm{IC}_{50}$ of the Cymbopogon oil was found to be $5.7 \mu \mathrm{g} / \mathrm{ml}$ while that of Ocimum oil was $10.8 \mu \mathrm{g} / \mathrm{ml}$. The mixture of the oils $(1: 1 \mathrm{v} / \mathrm{v})$ showed an $\mathrm{IC}_{50}$ value of $10.2 \mu \mathrm{g} / \mathrm{ml}$ with no synergism in the cytotoxic activity [27].

\subsection{Antihypertensive Effect}

Intravenous treatment of conscious deoxycorticosterone acetate DOCA-salt hypertensive rats with the essential oil of O.gratissimum (EOOG) induced a hypotensive effect that seems related to an active vascular relaxation. To corroborate this hypothesis, the present study examined the vascular effects of EOOG and its main constituent, eugenol (EUG). In conscious DOCA-salt hypertensive rats, the EOOG-induced hypotension was reversible and remained unchanged by intravenous pretreatment with propranolol $(2 \mathrm{mg} / \mathrm{kg})$. In isolated aorta preparations with intact endothelium from DOCA-salt hypertensive rats, EOOG $(1-1000 \mu \mathrm{g} / \mathrm{mL})$ and EUG $(0.006-6 \mathrm{mM})$ relaxed the phenylephrine-induced contraction similarly with $\mathrm{IC}_{50}=226.9 \mu \mathrm{g} / \mathrm{mL}$ and $1.2(0.6-2.1)$ $\mathrm{mm}$, respectively. Vasorelaxant effects of EOOG were significantly altered by removal of the vascular endothelium $\mathrm{IC}_{50}=417.2 \mu \mathrm{g} / \mathrm{mL}$. In a calcium-free medium, the $\mathrm{CaCl}_{2}-$ induced contractions were significantly reduced and even abolished by EOOG at 300 and $1000 \mu \mathrm{g} / \mathrm{mL}$, respectively, whereas EOOG $(1000 \mu \mathrm{g} / \mathrm{mL})$ did not have any significant effect on caffeine-induced contractions. Similar results were obtained with EUG (1.8 and $6 \mathrm{mM})$ on both $\mathrm{CaCl}_{2}$ and caffeine-induced contractions, respectively. The data suggest that hypotensive responses to EOOG in DOCA-salt hypertensive rats are due to an active vascular relaxation, which is partly dependent upon the integrity of the vascular endothelium and seems predominantly mediated through an inhibition of plasmalemmal $\mathrm{Ca}_{2}{ }^{+}$influx rather than $\mathrm{Ca}_{2}{ }^{+}$induced $\mathrm{Ca}_{2}{ }^{+}$release from the sarcoplasmic reticulum [56].

The cardiovascular effects of intravenous treatment with the essential oil of $O$. gratissimum (EOOG) and its main constituent, eugenol (Eug) were investigated in the experimental model of deoxycorticosterone acetate (DOCA-salt)hypertensive rats. In both conscious DOCA-salt hypertensive rats and their uninephrectomized controls, intravenous bolus injections of EOOG $(1-20 \mathrm{mg} / \mathrm{kg})$ or Eug $(1-10 \mathrm{mg} / \mathrm{kg})$ induced dose-dependent hypotension and bradycardia. Treatment with DOCA-salt significantly enhanced the maximal decreases in mean aortic pressure (MAP) elicited by hexamethonium (30 mg/kg, intravenous) as well as the hypotensive responses to both EOOG and Eug without affecting the bradycardia. However, the enhancement of EOOG-induced hypotension in hypertensive rats remained unaffected by intravenous pretreatment with either hexamethonium (30 $\mathrm{mg} / \mathrm{kg})$ or methylatropine $(1 \mathrm{mg} / \mathrm{kg})$. These results show that intravenous treatment with EOOG or Eug dose-dependently decreased blood pressure in conscious DOCA-salt hypertensive rats, and this action is enhanced when compared with uninephrectomized controls. This enhancement appears related mainly to an increase in EOOG-induced vascular smooth relaxation rather than to enhanced sympathetic nervous system activity in this hypertensive model [57].

\subsection{Cardiovascular Effect}

The cardiovascular effects of intravenous administration of the essential oil of $O$. gratissimum (EOOG) were investigated in rats. The present study examined: (i) whether the autonomic nervous system is involved in the mediation of EOOG-induced changes in mean aortic pressure (MAP) and heart rate (HR); and (ii) whether these changes could be attributed, at least in part, to the actions of eugenol, the major constituent of EOOG. In both pentobarbitone-anaesthetized and conscious rats, intravenously administered bolus injections of EOOG $(1-20 \mathrm{mg} / \mathrm{kg})$ elicited immediate and dosedependent decreases in MAP and HR. These responses to EOOG were of the same order of magnitude irrespective of whether the animal was under general anaesthesia. Pretreatment of anaesthetized rats with bilateral vagotomy did not significantly modify the EOOG-induced dose-dependent hypotension, whereas it significantly reduced the bradycardia at the highest dose used. In conscious rats, intravenous injections of bolus doses (1-10 mg/kg) of eugenol also elicited immediate and dose-dependent decreases in MAP and HR. Intravenous pretreatment of conscious rats with either methylatropine $(1 \mathrm{mg} / \mathrm{kg})$ or hexamethonium $(30 \mathrm{mg} / \mathrm{kg})$ significantly reduced the EOOG-induced dose-dependent bradycardia without affecting the hypotension. These data show, for the first time, that intravenous administration of EOOG to either anaesthetized or conscious rats induces an immediate and significant hypotension and bradycardia, which appear to be due, at least in part, to the actions of the major constituent of EOOG, eugenol. This may suggest that the hypotensive activity of EOOG results from its vasodilatory effects directly upon vascular smooth muscle [58].

\subsection{Immunostimulatory Effect}

Immunostimulatory activity of ethanolic leaf extract of O. gratissimum was investigated in albino rats using immunologic/haematologic indices. The rats were dosed orally with standard inoculum of E. coli (NCIB 86) of $1 \times 10^{7}$ $\mathrm{cfu} / \mathrm{ml}$. The extent of infection was carried out by checking the haematologic indices before, during and after treating the infection with ethanolic extract of $O$. gratissimum. The animals were divided into four groups. The first group was dosed with $8 \mathrm{ml}$ of the standard inoculum for two days. The second group was dosed with the standard inoculum and treated with $250 \mathrm{mg} / \mathrm{ml}$ of $O$. gratissimum ethanolic leaf extract. The third group was dosed with the extract alone while the fourth group was given normal saline and this serve as the control. The infected rat that was not given the extract showed a WBC count of $4,800 \mathrm{~mm}^{3}$ before infection and increased to $13,800 \mathrm{~mm}^{3}$ during infection and later decreased to $2,400 \mathrm{~mm}^{3}$ after oral administration of the extract. The Packed Cell Volume (PCV) was 57\% before infection, $47 \%$ during infection and $35 \%$ after treatment. The neutrophil and lymphocyte percentage in the differential count were 48 and $51 \%$ before infection, 62 and $37 \%$ during infection and 74 and $26 \%$ after treatment of infection respectively. For the rats treated with extract, it showed a WBC count of 5,000 $\mathrm{mm}^{3}$ before infection, which decreased to $3,000 \mathrm{~mm}^{3}$ during infection and $1,700 \mathrm{~mm}^{3}$ after infections. It had a PCV, neutrophil and lymphocyte value of 55, 47 and $52 \%$ before infection, 50, 42 and 58\% during infection and 33, 44, 56\% after infection. The rats given the extract of $O$. gratissimum 
alone showed a value of $4,400 \mathrm{~mm}^{3}, 48,41$ and $58 \%$ for the WBC, PCV, neutrophil and lymphocyte before infection, a value of $3,200 \mathrm{~mm}^{3}, 63,43$ and $57 \%$ during infection and a value of $2,100 \mathrm{~mm}^{3}, 25,42$ and $56 \%$, respectively after infection. The control showed only a significant increase in WBC with a value of $4,000 \mathrm{~mm}^{3}$ before infection, to 6,100 $\mathrm{mm}^{3}$ after infection and back to $4,400 \mathrm{~mm}^{3}$ after infection. The urinalysis showed a $\mathrm{pH}$ value of 5, was negative for glucose, ascorbic acid, ketone, nitrite, protein and bilirubin, normal for urobilinogen and negative blood value for all the groups before infection. The infected rat without administration of extract showed a $\mathrm{pH}$ of 7 and became positive for ketone, nitrite, protein and bilirubin urobilinogen and blood value of $\mathrm{Ca}$. 250 during infection while others remain the same. After infection, the $\mathrm{pH}$ turned to 6 , became negative for other parameters except protein and bilirubin while the treated rats remain negative. The ethanolic leaf extract of O.gratissimum was found effective in inhibiting/preventing the disease condition after infection and was capable of reducing excessive breakdown of red blood cells and neutralizing toxin produced by the organism [59].

\subsection{Antidiabetic Effect}

The hypoglycemic effects of the aqueous leaves extract of $O$. gratissimum was investigated in streptozocin-induced diabetic rats. The extract was administered once at the dose of 250,500 and $1000 \mathrm{mg} / \mathrm{kg}$ body weight. The aqueous extract at the dose of $500 \mathrm{mg} / \mathrm{kg}$ significantly lowered blood glucose level $(\mathrm{P}<0.05)$ of the diabetic rats by $81.3 \%$ after 24 $\mathrm{h}$ of extract administration. Preliminary phytochemical screening revealed the presence of reducing sugars, cardiac glycosides, resin, tannins, saponins, glycosides, flavonoids, glycerin and steroids. The median lethal dose (LD50) in rats was calculated to be $1264.9 \mathrm{mg} / \mathrm{kg}$ body weight. The leaves extract of $O$. gratissimum was reported to possess antidiabetic activity in streptozocin-induced in diabetic rats [60].

\subsection{Hepatoprotective Effect}

Aqueous extract of the leaves of $O$. gratissimum were used to evaluate the hepatoprotective and diuretic effects. Extracts were administered orally by means of polvthene cannula to male rabbits. The drug given at dose of $0.4 \mathrm{~g} / \mathrm{kg}$ body weight showed increase in luminal diameter of the collecting duct. At $0.8 \mathrm{~g} / \mathrm{kg}$ body weight further increase in luminal diameter was observed. Marked increase in the luminal diameter of the renal tubules was observed when the extract dose was increased to $1.6 \mathrm{~g} / \mathrm{kg}$ body weight, showing a dose response effect of the extract on the structure of the kidney, thus indicating the use of $O$. gratissimum as an diuretic. The structure of the liver also showed dose-dependent changes when exposed to various doses of the extract. At a dose of $0.4 \mathrm{~g} / \mathrm{kg}$ body weight of the extract, there was a generalized edema/hypertrophy of the hepatocytes resulting in a marked widespread, sinusoidal congestion. About $80 \%$ of the hepatocytes showed cytoplasmic compaction and disintegration, with some apoptotic bodies as well as nuclear piknosis. Kupfer cells were many and were trapped within the sinusoids indicating a degenerative/necrotic process. Increasing the dose of extract to $0.8 \mathrm{~g} / \mathrm{kg}$ body weight produced similar results. There was a reduction in all the parameters observed. There was less hepatocytic edema/hypertrophy resulting in slightly widened sinusoidal spaces. Hepatocytes showed reduced cytoplasmic compaction and disintegration with less prominent apoptotic bodies. In addition there was mild leukocyte infiltration and compaction was observed in the hepatocytes with mild tissue lesion or damage as compared with the $0.4 \mathrm{~g} / \mathrm{kg}$ treated group. The group of animals treated with $1.6 \mathrm{~g} / \mathrm{kg}$ of the extract depicted a reestablishment of the normal structure of the liver. Hepatocytes showed no sign of oedema hvpertrophy resulting in sinusoids with larger (normal) diameter thereby indicating the usefulness of $O$. gratissimum as an hepatoprotective agent [2].

\subsection{Hair Loss}

Hair loss is one of the most feared side effects of cancer chemotherapy. Preliminary study investigated by Orafidiya et al. showed the efficacy of the leaf essential oil of $O$. gratissimum (Ocimum oil) in promoting hair growth in cyclophosphamide-induced hair loss. Shaved sites, $4 \mathrm{~cm}^{2}$, were created on the flanks of 6 groups each of 7 freshly weaned 4week old rats. Four groups (groups 2, 4, 5 and 6) were treated with $30 \mathrm{mg} / \mathrm{kg}$ cyclophosphamide i. p. daily to simulate changes seen in human chemotherapy-induced hair loss. Ocimum oil was administered topically alone (group 3 ) or in combination with cyclophosphamide in groups 2, 4 and 5 for 14 days and in group 6 for 8 days. Group 1 received no test substance. Tissue biopsies were obtained from 2 rats selected at random from each group on treatment day 9 for histological examination. Surviving animals were further observed for 7 days after treatment. Histopathology and gross morphologic observations for hair re-growth at shaved sites revealed active follicular proliferation in Ocimum alone and cyclophosphamide + Ocimum oil treated groups. Ocimum oil may, therefore, be capable of enhancing normal hair growth and promoting follicular proliferation in cyclophosphamide-induced hair loss [61].

\subsection{Antioxidant Capacity}

The antioxidant capacity of essential oils obtained by steam hydrodistillation from five species of the genus Ocimum were evaluated using a high-performance liquid chromatography-based hypoxanthine/xanthine oxidase and DPPH assays. The yield of oils from the leaves of the five species was variable with the greater amount obtained from O.gratissimum (3.5\%). In the hypoxanthine/xanthine oxidase assay, strong antioxidant capacity was evident in all the oils. Antioxidant capacity was positively correlated $(r=0.92$, $p<0.05$ ) with a high proportion of compounds possessing a phenolic ring such as eugenol, while a strong negative correlation $(r=-0.77, p>0.1)$ with other major volatiles was observed. These correlations were confirmed to a large extent in the DPPH assay. The data generated with Ocimum species indicates that essential oils obtained from various herbs and spices may have an important role to play in cancer chemoprevention, functional foods, and in the preservation of pharmacologic products [62].

Extracts from the leaves of $O$. gratissimum were investigated for their phytochemical constituents and for antioxidant activity. Tests for tannins, steroids, terpenoids, flavonoids and cardiac glycosides were positive in both methanolic and aqueous extracts. The methanolic extract of $O$. gratissimum had a DPPH scavenging activity of $84.6 \%$ at 250 
$\mu \mathrm{g} / \mathrm{ml}$ and a reductive potential of 0.77 at $100 \mu \mathrm{g} / \mathrm{ml}$. These values were comparable with those of gallic acid, $91.4 \%$ at $250 \mu \mathrm{g} / \mathrm{ml}$ and ascorbic acid, 0.79 at $60 \mu \mathrm{g} / \mathrm{ml}$ as standards for DPPH scavenging activity and reductive potential, respectively. These findings suggest the rich phytochemical content of $O$. gratissimum and its good antioxidant activity [4].

\subsection{Suspending Activity}

Mucilage extracted from $O$. gratissimum seeds were subjected to toxicity studies for its safety and preformulation studies for its suitability as a suspending agent. Zinc oxide suspensions were prepared and compared with different concentrations of O.gratissimum mucilage, tragacanth and sodium CMC. The mucilage extracted is devoid of toxicity. The mucilage was found to be a superior suspending agent to tragacanth and was comparable to sodium CMC. Studies indicate that the extracted mucilage may be a good pharmaceutical adjuvant, specifically a suspending agent [63].

\subsection{Central Nervous System Activity}

Cristiana M. Murbach Freire et al. carried out the study to investigate whether seasonal variations in composition of essential oil of $O$. gratissimum are accompanied by changes in pharmacological properties; using experimental procedures to investigate the central nervous system activity. The essential oils obtained in each season were capable of increasing the barbiturate-induced sleeping duration. The greatest effect was obtained with the preparation from autumn, and the least effect was observed with that from winter, which was not active in the lesser dose administered. Eugenol was the most abundant compound in the essential oil from each season, with the greatest relative percentage detected in autumn $(56.10 \%)$. The greatest activity (enhanced 7.9 times in relation to their TW group) was observed in the preparation from autumn, which had $16.83 \%$ 1,8-cineole. Essential oil collected in spring (27.13\%) increased 3.1 times the duration of sleep, in summer (32.5 8\%) the increase was 3.0 -fold while in winter $(33.67 \%)$ the increase was 2.5 times. The phytoconstituent 1,8 -cineole is a monoterpene that has stimulant activity upon CNS. Thus, it is possible to suggest that the decrease in the amount of this compound facilitates increase in sleeping time [6].

\section{ANTICONVULSANT ACTIVITY}

The experimental models used to evaluate the anticonvulsant activity, MES and PTZ tests, are assumed to identify anticonvulsant drugs effective against generalized tonicclonic partial seizures and generalized clonic seizures, respectively. The anticonvulsant activity observed in the essential oil from $O$. gratissimum extracted in the Spring could be also related to the higher amount of sesquiterpenes. In fact, synergic effect among compounds could not be discarded, since minor compounds such as linalool and myrcene present sedative and/or anticonvulsive effects [64].

\subsection{Nematicidal Activity}

Nematicidal activity was attributed to eugenol reported to be earlier as major component of the $O$. gratissimum oil by Chatterje et al. 1982 [65].

\subsection{Disintegrating Activity}

Ravikumar et al. carried out study on the disintegrant properties of seed mucilage of $O$. gratissimum. It was found that the disintegration time of tablet in oral cavity was found between $43-68 \mathrm{~s}$ and $45-65 \mathrm{~s}$ for $O$. gratissimum mucilage powder, and seed powder respectively. Wetting time was found between $40-88 \mathrm{~s}$ and $38-75 \mathrm{~s}$ for $O$. gratissimum mucilage powder and seed powder respectively. All designed formulations using $O$. gratissimum mucilage powder and seed powder showed rapid dissolution and percent cumulative drug release at the end of $5 \mathrm{~min}$ was $75-97 \%$ for all formulations. The conventional marketed tablet of Metformin $\mathrm{HCl}$ required around $35 \mathrm{~min}$. for same amount of drug to be released [66].

\section{CLINICAL STUDIES}

A recent study tested a range of concentrations of $O$. gratissimum oil in comparison to $10 \%$ benzoyl peroxide and a placebo, over a period of 4 weeks, for the reduction of acne lesions in a population consisting mainly of students. $O$. gratissimum oil was incorporated at concentrations of $0.5 \%$, $1 \%, 2 \%$ and $5 \% \mathrm{v} / \mathrm{v}$ in four different bases (polysorbate 80 , cetomacrogol, petrolatum and alcohol) resulting in 16 parallel experimental groups. The numbers of lesions were counted daily by investigators throughout the test period and the time taken to achieve a $50 \%$ reduction relative to pretreatment was noted for each subject. Preparations containing $2 \%$ and $5 \%$ Ocimum oil in alcohol and $5 \%$ in cetomacrogol were significantly more active than benzoyl peroxide $(P<0.05)$, while $2 \%$ oil in cetomacrogol had similar activity to the reference product. The most active $5 \%$ preparations produced skin irritation but the authors considered a $2 \%$ preparation in cetomacrogol to be suitable for the management of acne [67].

Another clinical study was carried out by the same author using a combination of $O$. gratissimum and Aloe vera gel. The study was carried out as follows. 84 subjects presenting with clinically significant Acne vulgaris, were randomly assigned into seven groups and treated with different test preparations $(2 \% \mathrm{v} / \mathrm{v}$ Ocimum oil lotion containing graded concentrations $(0-\approx 100 \%)$ of aloe gel, placebo or control preparations). Samples tested were applied to the face after washing morning and evening. The numbers of inflammatory lesions (papules and pustules) were counted prior to application and daily for 4 weeks. The efficacy of the preparations was rated in terms of product activity $(1 / D)$, which is the reciprocal value of the number of days taken to achieve $50 \%$ reduction in lesion count. It was found that Aloe vera gel enhanced the antiacne properties of Ocimum oil. The oil or its combination with aloe vera gel was found to be effective than $1 \%$ Clindamycin in the treatment of Acne vulgaris [68].

\section{TOXICOLOGY}

Oral and intraperitoneal acute toxicity and the sub chronic intraperitoneal toxicity of the essential oil of $O$. gratissimum was investigated. The acute toxicity test involved oral and intraperitoneal administration of graded doses of Ocimum oil prepared as a $4 \% \mathrm{v} / \mathrm{v}$ emulsion to 2 groups each of 30 rats and mice. $\mathrm{LD}_{50}$ and $\mathrm{LD}_{100}$ were determined for both routes and species. In the sub chronic tox- 
icity study, 25 male Sprague-Dawley rats were randomized into 4 test groups and a control. Organs and blood samples were taken for analyses after a 30 days treatment period. A dose dependent sedative effect of Ocimum oil was observed during the acute toxicity study in mice and rats and in the subchronic test in mice and rats. Evidence of treatment, route, and dose-dependent toxicity were detected in both studies. Change in weight of the testes, hearts, kidney, intestines and lungs of the rats were statistically insignificant. Data analysis of blood biochemical, haemotological and histopathological findings showed significant differences between control and treated groups and revealed that Ocimum oil is capable of invoking an inflammatory response that transits from acute to chronic on persistent administration. While the study revealed that Ocimum oil might be better tolerated when orally for systemic delivery, the oil has toxic potentialities that should not be overlooked [69].

It was also reported that $O$. gratissimum can affect macrophage functioning and can also be hepatocarcinogenic [70].

\section{CONCLUSION}

This review has covered the morphology and microscopy, natural products, pharmacology and clinical studies of the plant $O$. gratissimum. $O$. gratissimum is a plant with much potential and is useful in many diseases. Hence this article will be useful to those researchers interested in validating the hidden truth which has not been scientifically validated

Presently there is an increasing interest worldwide in herbal medicines accompanied by increased laboratory investigation into the pharmacological properties of the bioactive ingredients and their ability to treat various diseases [7173]. Numerous drugs have entered the international market through exploration of ethnopharmacology and traditional medicine. Although scientific studies have been done on a large number of Indian botanicals, a considerably smaller number of marketable drugs or phytochemical entities have entered the evidence-based therapeutics.

\section{REFERENCES}

[1] Nadkarni KM. Indian Materia Medica, $3^{\text {rd }}$ ed. Popular Prakashan Pvt Ltd: India 1999.

[2] Effraim KD, Jacks TW, Sodipo OA. Histopathological studies on the toxicity of Ocimum gratissimum leave extract on some organs of rabbit. Afr J Biomed Res 2003; 6: 21-5.

[3] Rabelo M, Souza EP, Soares PMG, et al. Antinociceptive properties of the essential oil of Ocimum gratissimum L. (Labiatae) in mice. Braz J Med Biol Res 2003; 36: 521-4.

[4] Akinmoladun AC, Ibukun EO, Emmanuel A, Obuotor EM, Farombi EO. Phytochemical constituent and antioxidant activity of extract from the leaves of Ocimum gratissimum. Sci Res Essay 2007; 2: 163-6.

[5] Ijeh II, Omodamiro OD, Nwanna IJ. Antimicrobial effects of aqueous and ethanolic fractions of two spices, Ocimum gratissimum and Xylopia aethiopica. Afr J Biotech 2005; 4: 953-6.

[6] Cristiana M, Murbach F, M'arcia OM, Mirtes C. Effects of seasonal variation on the central nervous system activity of Ocimum gratissimum L. essential oil. J Ethnopharmacol 2006; 105: 161-6.

[7] Matasyoh LG, Josphat CM, Francis NW, Miriam GK, Anne WTM, Titus KM. Chemical composition and antimicrobial activity of the essential oil of Ocimum gratissimum L. growing in Eastern Kenya. Afr J Biotech 2007; 6: 760-5.

[8] Prajapati ND, Purohit SS, Sharma AK, Kumar T. Agro's dictionary of medicinal plants. $1^{\text {st }}$ ed. Agrobios: India 2003.
[9] Oliver B, Medicinal plants in Nigeria. Nigerian College of Arts, Science and Technology: lbadan 1980.

[10] Ta^nia Ueda, Nakamura RR, Mendonca F, et al. Antileishmanial activity of Eugenol-rich essential oil from Ocimum gratissimum. Parasitol Int 2006; 55: 99-105.

[11] Kabir OA, Olukayode O, Chidi EO, Christopher CI, Kehinde AF. Screening of crude extracts of six medicinal plants used in SouthWest Nigerian unorthodox medicine for anti-methicillin resistant Staphylococcus aureus activity. BMC Complement Altern Med 2005; 5: 1-7.

[12] Adebolu TT, Salau AO. Antimicrobial activity of leaf extracts of Ocimum gratissimum on selected diarrhoea causing bacteria in southwestern Nigeria. Afr J Biotech 2005; 4: 682-4.

[13] Ngassoum MB, Jessia-Ngang JJ, Tatsadjieu LN, Jirovetz L, Buchbauer G, Adjoudji O. Antimicrobial study of essential oils of Ocimum gratissimum leaves and Zanthoxylum xanthoxyloides fruits from Cameroon. Fitoterapia 2003; 74: 284-7.

[14] Orafidiya LO, Oyedele AO, Shittu AO, Elujoba AA. The formulation of an effective topical antibacterial product containing Ocimum gratissimum leaf essential oil. Int J Pharm 2001; 224: 177-83.

[15] Bhat KG. Flora of Udupi. $1^{\text {st }}$ ed. Indian Naturalist: India 2003.

[16] García LD, Sandra PT, Crespo M. Lic. Leticia Fuentes. Study farmacognóstico of Ocimum gratissimum L. (Cimarrón oregano). Rev Plant Cuban 1998; 3: 31-6.

[17] Satyavati GV, Gupta AK, Neeraj T. Medicinal plants of India. ICMR, New Delhi: India 1987; vol 2.

[18] Tharanathan RN, Shamanna D. Composition of OcimumGratissimum Shrubby Basil Seed Mucilage. Indian J Chem 1975; 13: 307-8.

[19] Janine AL, Xisto SP, Orionalda FLF, José RP, Pedro HF, Lúcia KHS, Aline AL, Maria RRS. Antifungal activity from Ocimum gratissimum $L$. towards Cryptococcus neoformans. Mem Inst Oswaldo Cruz 2005; 100: 55-8.

[20] Iwalokun BA, Gbenle GO, Adewole TO, Smith SI, Akinsinde KA, Omonigbehin EO. Effects of Ocimum gratissimum L. essential oil at subinhibitory concentrations on virulent and multidrug-resistant Shigella strains from Lagos, Nigeria. Acta Pathologic Microbiol Immunol Scand 2003; 111: 477-82.

[21] Kéita SK, Vincent C, Jean-Pierre S, Bélanger A. Essential oil composition of Ocimum basilicum L., O. gratissimum L. and $O$. suave L. in the Republic of Guinea. Flav Fragr J 2000; 15: 339-41.

[22] Lawrence BM. Progress in Essential oils: Ocimum gratissimum oil. Perfum Flavor 1997; 22: 70-4.

[23] Maria GVS, Francisco JAM, Paulo ROL, Fábio OS, Márcio TH. Composition of essential oils from three Ocimum species obtained by steam and microwave distillation and supercritical $\mathrm{CO}_{2}$ extraction. ARKIVOC 2004; 6: 66-71.

[24] Pandey AK, Chowdhury AR. Composition of the essential oil of Ocimum gratissimum grown in Madhya Pradesh. J Med Aromat Plant Sci 2000; 22-23, 26-8.

[25] Onajobi FD. Smooth muscle contracting lipid-soluble principles in chromatographic fractions of Ocimum gratissimum. J Ethnopharmacol 1986; 18: 3-11.

[26] Terezinha JF, Rafael SF, Lidiane Y, José RPS, Noemia KI, Aneli MB. Antifungal Activity of Essential Oil Isolated from Ocimum gratissimum L. (eugenol chemotype) against Phytopathogenic Fungi. Braz Arch Biol Technol 2006; 49:867-71.

[27] Dubey NK, Kishore N, Varma J, Lee SY. Cytotoxicity of the essential oils of Cymbopogon citratus and Ocimum gratissimum. Indian J Pharm Sci 1997; 59:263-4.

[28] Jirovetz L, Buchbauer G, Ngassoum MB, Ngamo LT, Adjoudji O. Combined investigation of the chemical composition of essential oils of Ocimum gratissimum and Xylopia aethiopica from Cameroon and their insecticidal activities against stored maize pest Sitophilus zeamais. Ernähr 2005; 29: 55-60.

[29] Offiah VN, Chikwendu UA. Antidiarrhoeal effects of Ocimum gratissimum leaf extract in experimental animals. J Ethnopharmacol 1999; 68: 327-30.

[30] Njoku CJ, Zeng L, Asuzu IU, Oberlies NH, Mclaughlin JL. Oleanolic acid, a bioactive component of the leaves of Ocimum gratissimum (lamiaceae). Int J Pharmacognosy 1997; 35: 134-7.

[31] Vasconcelos Silva MG, Craveiro AA, Abreu Matos FJ, Machado MIL, Alencar JW. Chemical variation during daytime of constituents of the essential oil of Ocimum gratissimum leaves. Fitoterapia 1999; 70: 32-4. 
[32] Orafidiya LO, Adesina SK, Igbeneghu OA, Akinkunmi EO, Adetogun GE, Salau AO. The effect of honey and surfactant type on the antibacterial properties of the leaf essential oil of Ocimum gratissimum Linn. against common wound-infecting organisms. Int J Aromatherapy 2006; 16: 57-62.

[33] Nakamura CV, Ueda-Nakamura T, Bando E, Melo AFN, Cortez DAG, Filho BPD. Antibacterial activity of Ocimum gratissimum L. essential oil. Mem Inst Oswaldo Cruz 1999; 94: 675-8.

[34] Akinyemi KO, Oladapo O, Okwara CE, Ibe CC, Fasure KA. Screening of crude extracts of six medicinal plants used in SouthWest Nigerian unorthodox medicine for anti-methicillin resistant Staphylococcus aureus activity. BMC Complement Altern Med 2005; 5: 6-10.

[35] Lima EO, Gompetz OF, Giesbrecht AM, Paulo MQ. In vitro antifungal activity of essential oils obtained from officinal plant against dermatophytes. Mycoses 1993; 36: 333-6.

[36] Mbata TI, Saikia A. Antibacterial Activity of Essential oil from Ocimum gratissimum on Listeria monocytogenes. Int J Food Safety 2007; 7:15-9.

[37] Okigbo RN, Ogbonnaya UO. Antifungal effects of two tropical plant leaf extracts (Ocimum gratissimum and Aframomum melegueta) on postharvest yam (Dioscorea spp) rot. Afr J Biotech 2006; 5: 727-31.

[38] Fandohan P, Gbenou JD, Nonlonfin B, et al. Effect of essential oils on the growth of Fusarium verticillioides and fumonisin contamination in Corn. J Agric Food Chem 2004; 52: 6824-9.

[39] Silva MRR, Oliveira Júnior JG, Fernandes OFL, et al. Antifungal activity of Ocimum gratissimum towards dermatophytes. Mycoses 2005; 48: 172-5.

[40] Usip LPE, Opara KN, Ibanga ES, Atting IA. Longitudinal evaluation of repellent activity of Ocimum gratissimum (Labiatae) volatile oil against Simulium damnosum. Mem Inst Oswaldo Cruz 2006; 101: 201-5.

[41] Holetz FB, Ueda-Nakamura T, Filho BPD, Cortez DAG, MorgadoDíaz JA, Nakamura CV. Effect of essential oil of Ocimum gratissimum on the Trypanosomatid Herpetomonas samuelpessoai. Acta Protozool 2003; 42: 269-76.

[42] Alabi DA, Oyero IA, Jimoh Amusa NA. Fungitoxic and phytotoxic effect of Vernonia amygdalina (L), Bryophyllum pinnantus Kurz Ocimum gratissimum (Closium) L. and Eucalyptna globules (Caliptos) Labill Water Extracts on Cowpea and Cowpea Seedling Pathogens in Ago-Iwoye, South Western Nigeria. World J Agric Sci 2005; 1: 70-5

[43] Amadioha AC, Obi VI. Control of anthracnose disease of cowpea by Cymbopogon citratus and Ocimum gratissimum. Acta Phytopathol Entomol Hungarica 1999; 34: 85-690.

[44] Pessoa LM, Morais SM, Bevilaqua CML, Luciano JHS. Anthelmintic activity of essential oil of Ocimum gratissimum Linn. and eugenol against Haemonchus contortus. Veterinary Parasitol 2002; 109: 59-63.

[45] Luize PS, Tiuman TS, Morello LG, et al. Effects of medicinal plant extracts on growth of Leishmania (L.) amazonensis and Trypanosoma cruzi. Braz J Pharm Sci 2005; 41: 85-95.

[46] Tchoumbougnang F, Zollo PH, Dagne E, Mekonnen Y. In vivo antimalarial activity of essential oils from Cymbopogon citratus and Ocimum gratissimum on mice infected with Plasmodium berghei. Planta Med 2005; 71: 20-3.

[47] Ilori MO, Sheteolu AO, Omonigbehin EA, Adeneye AA. Antidiarrhoeal activities of Ocimum gratissimum (Lamiaceae). J Diarrhoeal Dis Res 1996; 14: 283-6.

[48] Ezekwesili CN, Obiora KA, Ugwu OP. Evaluation of antidiarrhoeal property of crude aqueous extract of Ocimum gratissimum L. (Labiatae) in rats. Biokemistri 2004; 16: 122-31.

[49] Madeira SVF, Matos FA, Leal-Cardoso JH, Criddle DN. Relaxant effects of the essential oil of Ocimum gratissimum on isolated ileum of the guinea pig. J Ethnopharmacol 2002; 81: 1-4.

[50] Owulade MO, Eghianruwa KI, Daramola FO. Effects of aqueous extracts of Hibiscus sabdariffa calyces and Ocimum gratissimum leaves on intestinal transit in rats. Afr J Biomed Res 2004; 7: 31-3.

[51] Madeira SVF, Rabelo M, Soares PMG, et al. Temporal variation of chemical composition and relaxant action of the essential oil of Ocimum gratissimum L. (Labiatae) on guinea-pig ileum. Phytomedicine 2005; 12: 506-9.

[52] Orafidiya LO, Fakoya FA, Agbani EO, Iwalewa EO. Vascular permeability- increasing effect of the leaf essential oil of Ocimum gratissimum Linn as a mechanism for its wound healing property. Afr J Trad CAM 2005; 2: 253-8.

[53] Sahouo GB, Tonzibo ZF, Boti B, Chopard C, Mahy JP, N'guessan YT. Anti- inflammatory and analgesic activities: Chemical constituents of essential oils of Ocimum gratissimum, Eucalyptus citriodora and Cymbopogon giganteus inhibited lipoxygenase L-1 and cyclooxygenase of PGHS. Bull Chem Soc Ethiopia 2003; 17: 191-7.

[54] Aziba PI, Bass D, Elegbe Y. Pharmacological investigation of Ocimum gratissimum in rodents. Phytother Res 1999; 13: 427-9.

[55] Obaseiki-Ebor EE, Odukoya K, Telikepalli H, Mitscher LA, Shankel DM. Antimutagenic activity of extracts of leaves of four common edible vegetable plants in Nigeria (West Africa). Mutat Res 1993; 2: 109-17.

[56] Interaminense LF, Jucá DM, Magalhães PJ, Leal-Cardoso JH, Duarte GP, Lahlou S. Pharmacological evidence of calciumchannel blockade by essential oil of Ocimum gratissimum and its main constituent, eugenol, in isolated aortic rings from DOCA-salt hypertensive rats. Fundam Clin Pharmacol 2007; 21: 497-506.

[57] Interaminense LFL, Leal-Cardoso JH, Magalhães PJC, Duarte GP, Lahlou S. Enhanced hypotensive effects of the essential oil of Ocimum gratissimum leaves and its main constituent, eugenol, in DOCA-salt hypertensive conscious rats. Planta Medica 2005; 71: 376-8.

[58] Lahlou S, Interaminense LDFL, Leal-Cardoso JH, Morais SM, Duarte GP. Cardiovascular effects of the essential oil of Ocimum gratissimum leaves in rats: Role of the autonomic nervous system. Clin Exp Pharmacol Physiol 2004; 31: 219-25.

[59] Oladunmoye MK. Immunostimulatory Activity of ethanolic leaf extract from Ocimum gratissimum in albino rat orogastrically dosed with Escherichia coli (NCIB 86). J Pharmacol Toxicol 2006; 1: 389-94.

[60] Mohammed A, Tanko Y, Okasha MA, Magaji RA, Yaro AH. Effects of aqueous leaves extract of Ocimum gratissimum on blood glucose levels of streptozotocin induced diabetic wistar rats. Afr J Biotechnol 2007; 6: 2087-90.

[61] Orafidiya LO, Agbani EO, Adelusola KA, et al. A study on the effect of the essential oil of Ocimun gratissimum Linn. on cyclophosphamide induced inhibited hair growth in pulp rats. Int J Aromather 2004; 14: 119-28.

[62] Trevisan MTS, Silva MGV, Pfundstein B, Spiegelhalder B, Owen RW. Characterization of the volatile pattern and antioxidant capacity of essential oils from different species of the genus Ocimum. J Agric Food Chem 2006; 54: 4378-82.

[63] Anroop B, Bhatnagar SP, Ghosh B, Parcha V. Studies on Ocimum gratissimum seed mucilage: evaluation of suspending properties. Indian J Pharm Sci 2005; 67: 206-9.

[64] Löscher W, Schmidt D. Which animal models should be used in the search for new antiepileptic drugs? A proposal based on experimental and clinical considerations, Epilepsy Res 1988; 2: 14581

[65] Chatterje A, Sukul NC, Laskel S, Ghoshmajumadar S. Nematicides principal from two species of Lamiaceae. J Nematol 1982; 14: 11820.

[66] Ravikumar, Shirwaikar AA, Shirwaikar A, Prabu SL, Mahalaxmi R, Rajendran K, Kumar CD. Studies of disintegrant properties of seed mucilage of Ocimum gratissimum. Indian J Pharm Sci 2007; 69: 753-8.

[67] Orafidiya LO, Agbani EO, Oyedele AO, Babalola OO, Onayemi O Preliminary clinical tests on topical preparations of Ocimum gratissimum Linn leaf essential oil for the treatment of acne vulgaris. Clin Drug Invest 2002; 22: 313-9.

[68] Orafidiya LO, Agbani EO, Oyedele AO, Babalola OO, Onayemi O, Aiyedun FF. The effect of aloe vera gel on the anti-acne properties of the essential oil of Ocimum gratissimum Linn leaf - a preliminary clinical investigation. Int J Aromather 2004; 14: 15-21.

[69] Orafidiya LO, Agbani EO, Iwalewa EO, Adelusola KA, Oyedapo OO. Studies on the acute and sub-chronic toxicity of the essential oil of Ocimum gratissimum L. leaf. Phytomed 2004; 11: 71-6.

[70] Anthony JP, Fyfe L, Smith H. Plant active components - a resource for antiparasitic agents? Trends Parasitol 2005; 21: 462-8.

[71] Muller WEG, Schroder HC, Wiens M, Perovic-Ottstadt S, Batel R, Muller IM. Tarditional and modern biochemical prospecting: Part II-the benefits. Approaches for a sustainable exploitation of biodiversity (secondary metabolites in biomaterials from sponges). Evid. Based Complement. Altern Med 2004; 1: 133-44. 
[72] Muller WEG, Batel R, Schroder HC, Muller IM. Traditional and modern biomedical prospecting: Part-I-the history. Sustainable exploitation biodiversity (sponges and invertibrates) in the Adriatic sea at Rovinj (Croatia). Evid. Based Complement. Altern Med 2004; 1: 71-82.
[73] Cooper EL. Complementary and Alternative medicine, when rigorous, can be science. Evid. Based Complement. Altern Med 2004; 1 $1-4$.

Received: November 3, 2008

Revised: January 15, 2009

Accepted: January 27, 2009

(C) Prabhu et al.; Licensee Bentham Open.

This is an open access article licensed under the terms of the Creative Commons Attribution Non-Commercial License (http://creativecommons.org/licenses/ by-nc/3.0/) which permits unrestricted, non-commercial use, distribution and reproduction in any medium, provided the work is properly cited. 